\title{
Melting sea ice for taxonomic analysis: a comparison of four melting procedures
}

\author{
Ditte Marie Mikkelsen ${ }^{1} \&$ Anzdrej Witkowski ${ }^{2}$ \\ 1 Greenland Institute of Natural Resources, PO Box 570, DK-3900 Nuuk, Greenland \\ 2 University of Szczecin, Waska 13, PL-71-475 Szczecin, Poland
}

\section{Keywords}

Buffer; diatoms; direct melt; flagellates; osmotic stress; sea ice.

\section{Correspondence}

Ditte Marie Mikkelsen, Greenland Institute of Natural Resources, PO Box 570, DK-3900

Nuuk, Greenland. E-mail:

dittemikkelsen@gmail.com

doi:10.1111/j.1751-8369.2010.00162.x

\begin{abstract}
The influence of four melting procedures on the taxonomic composition of the sea-ice algal community in Kobbefjord, south-west Greenland, was investigated in April 2008. Direct melting (at 4 and $20^{\circ} \mathrm{C}$ ) was compared with melting in buffering seawater (with salinities of 10 and 30). The sea-ice algal community consisted of diatoms, cysts and several flagellate groups. Direct melting at $20^{\circ} \mathrm{C}$ differed significantly from one or more of the other melting procedures regarding the flagellate groups chrysophytes, chlorophytes, dinoflagellates and unidentified flagellates, whereas diatom, cyst and cryptophyte abundance was similar, regardless of the melting procedure. Apart from chrysophytes, the three other melting procedures (direct melting at $4^{\circ} \mathrm{C}$ and buffered in seawater with salinities of 10 and 30) were not statistically different. It is recommended that direct melting at $20^{\circ} \mathrm{C}$ is avoided, whereas the three slow melting procedures are all comparable. This will enable the future comparison of data from a wide geographic and historical range, thereby increasing our knowledge of sympagic algal communities.
\end{abstract}

During the course of sea-ice formation, consolidation and melt, a community of bacteria, viruses, algae and protozoa occupy the three-dimensional brine network. The sea-ice habitat is highly variable, both regarding chemical and physical parameters, and the primary producers of the system are diverse. Pennate diatoms are generally considered to be the dominant group (Medlin \& Priddle 1990).

Apparent geographic or temporal variations in the taxonomic composition of sea-ice algal communities may be real, but could also be caused by differences in methodology. Melting sea ice is an area of particular concern. When sea-ice samples are melted, the algae are exposed to a salinity change, and thus to osmotic stress, which may cause cells to lyse. Taxonomic analysis by microscopy subsequent to sea-ice melting may therefore be biased, depending on the susceptibility of the cells, and organisms with rigid cell material could be overestimated (Garrison \& Buck 1986). The consequence of osmotic stress during sea-ice melting could be an erroneous analysis of taxonomic composition.

One option to avoid the melting process is brine drainage, but as organisms attached to the ice lattice and caught in brine inclusions will not drain, sampling constitutes less than $5 \%$ of the sea-ice volume (Haecky $\&$ Andersson 1999). Although a comparison of sea-ice melting processes on a single ice floe showed similar community composition (Garrison \& Buck 1986), brine drainage may inadequately reflect the actual sea-ice algal community because of differences in, for example, the microhabitat (e.g., suspended or attached) and morphology (e.g., setae or mucoid substances) of sea-ice algae.

Taxonomic community studies should ideally include the entire sea-ice column, from top to bottom, ensuring that all organisms are sampled. Different approaches have been taken to mitigate osmotic stress during melting, most frequently by buffering the melting sea ice in an ample volume of pre-filtered seawater of known salinity (von Quillfeldt 1996, Ikävalko 1998). However, brine salinity varies temporally and vertically, e.g., from $<1$ to 70 over the course of a sea-ice season (Mikkelsen et al. 2008). Buffering sea-ice samples in seawater with a salinity of 33 would still cause the algae to experience osmotic stress. One way to reduce this osmotic stress would be to calculate the brine salinity immediately, and then use a 
seawater buffer of an appropriate salinity. However, the calculated brine salinity would still be an average value, and would not take into account, for example, brine inclusions that may experience even higher salinities. Osmotic stress can thus be decreased but not avoided when melting sea ice. Direct melting will also expose the sea-ice algae to osmotic stress, but gives the advantage of performing all measurements on the same core, and decreases the risk of contamination.

This study examines the effect of four melting procedures on the sea-ice algal community analysis: direct melting at 4 and $20^{\circ} \mathrm{C}$, and melting in buffering seawater with salinities of 10 and 30 .

\section{Methods}

Sea ice was sampled within an area of $1 \mathrm{~m}^{2}$ in Kobbefjord, Greenland, on 2 April $2008\left(64^{\circ} 09.34^{\prime} \mathrm{N}, 51^{\circ} 25.18^{\prime} \mathrm{W}\right.$; Fig. 1). Light intensity (LI-190SA Quantum Sensor; LI-COR Biosciences, Lincoln, NE, USA), air temperature (Testo 110 thermometer, Testo, Lenzkirch, Germany) and snow thickness were determined at the onset of sampling.

Sea-ice cores were taken using an ice auger (Mark III; Kovacs Enterprises, Lebanon, NH, USA). Both the sea-ice thickness and the bottom sea-ice temperature were measured (Testo 110 thermometer). The bottom $10 \mathrm{~cm}$ of the sea-ice cores were transported to the laboratory in polyethylene containers. The ice cores had a diameter of $7.25 \mathrm{~cm}$, and the volume of each sample was approximately $413 \mathrm{~cm}^{3}$.

The 12 sea-ice samples were melted in triplicate, as follows: (A) melted directly at $20^{\circ} \mathrm{C}$; (B) melted directly at $4^{\circ} \mathrm{C}$; (C) melted in $500 \mathrm{ml}$ of artificial seawater (salinity of 10) at $4^{\circ} \mathrm{C}$; (D) melted in $500 \mathrm{ml}$ of artificial seawater (salinity of 30 ) at $4^{\circ} \mathrm{C}$. The artificial seawater was made by dissolving $89.3 \mathrm{~g} \mathrm{NaCl}, 28.6 \mathrm{~g} \mathrm{MgSO}_{4} 7 \mathrm{H}_{2} \mathrm{O}$ and $0.13 \mathrm{~g}$ $\mathrm{NaHCO}_{3}$ in $1000 \mathrm{ml}$ of purified water (ELGA LabWater, Marlow, UK), and diluting to the appropriate salinity. All sea-ice samples were melted in the dark.

The conductivity of melted sea ice was measured (Orion 3-Star with Orion 013610MD conductivity cell; Thermo Fisher Scientific, Waltham, MA, USA) and converted to salinity (Grasshoff et al. 1983). Sea-ice brine salinity was calculated as a function of temperature (Cox \& Weeks 1983). A known volume of each sea-ice sample was filtered $(<0.1$ bar) using a glass microfibre filter with a diameter of $1.2 \mu \mathrm{m}$ (grade GF/C Glass Microfibre Filter; Whatman, Maidstone, Kent, UK) for chlorophyll determination. Chlorophyll was extracted in 96\% ethanol for $18 \mathrm{~h}$, and fluorescence was measured with a TD-700 fluorometer (Turner Designs, Sunnyvale, CA, USA). Melted sea-ice samples were preserved in Lugol's solution (to a final concentration of $1 \%$ ). For the taxonomic analysis and abundance calculation, melted sea-ice samples were studied by Utermöhl's (1958) method, using 25- and 50-ml Utermöhl chambers. Analyses were performed with an inverted microscope (Eclipse TE300; Nikon Instruments, Melville, NY, USA) equipped with $10 \times$ and $40 \times$ plan fluor objectives, and with a $60 \times(1.4$ numerical aperture) plan apochromat oil immersion objective, all with differential interference contrast.The magnification of the ocular was $10 \times$.

The Mann-Whitney $U$-test was applied to compare the melting methods one-on-one for the abundance and relative contribution of the identified taxa.

\section{Results}

When sampling the sea ice, the surface irradiance was $665 \mu \mathrm{mol}$ photons $\mathrm{m}^{-2} \mathrm{~s}^{-1}$ and the air temperature was

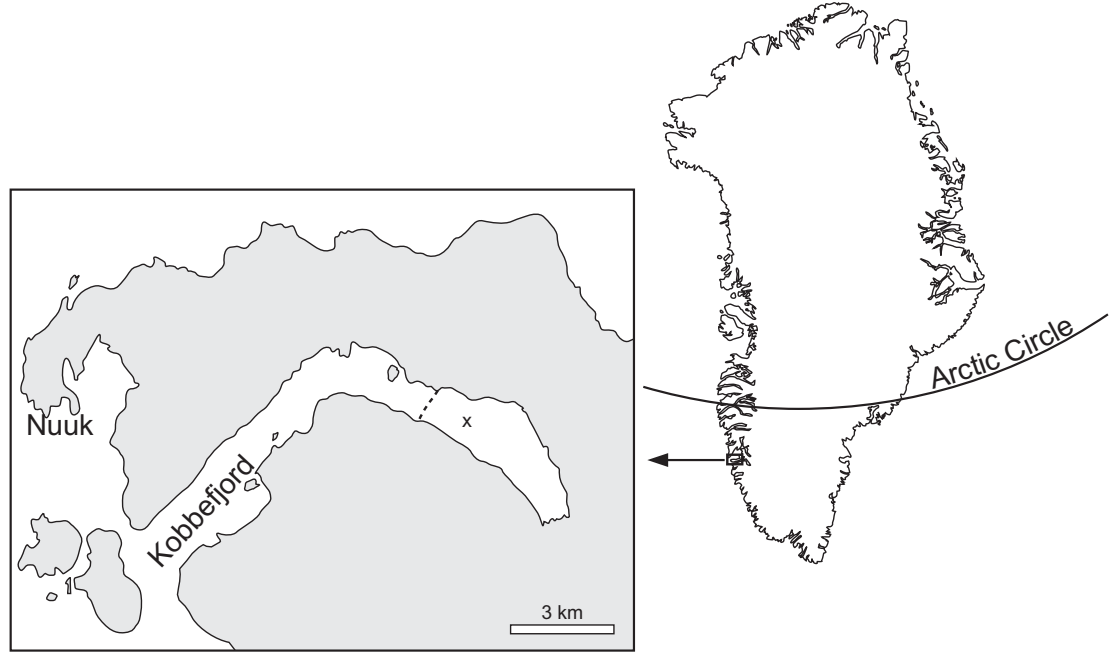

Fig. 1 Kobbefjord, south-west Greenland. The cross marks the sampling station and the dashed line marks the maximum sea-ice extent. 


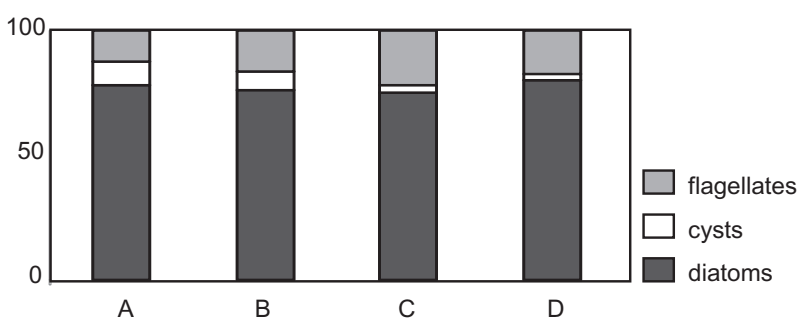

Fig. 2 Average taxonomic composition of the sea-ice algal community (\%, $n=3)$ : (A) direct melting $\left(20^{\circ} \mathrm{C}\right)$; (B) direct melting $\left(4^{\circ} \mathrm{C}\right)$; (C) buffered melting (salinity of 10); (D) buffered melting (salinity of 30).

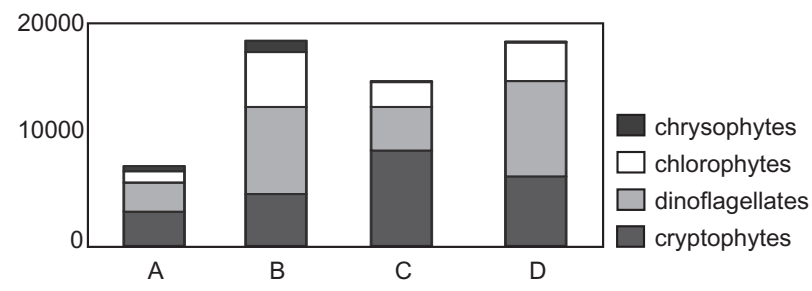

Fig. 3 Average taxonomic composition of the sea-ice algal community (\%, $n=3)$ : (A) direct melting $\left(20^{\circ} \mathrm{C}\right)$; (B) direct melting $\left(4^{\circ} \mathrm{C}\right)$; (C) buffered melting (salinity of 10); (D) buffered melting (salinity of 30).

$0.5^{\circ} \mathrm{C}$. Very little snow cover was present $(<2 \mathrm{~cm})$. The sea ice was $42-43 \mathrm{~cm}$ thick, with no slush ice and little snow cover $(<5 \mathrm{~cm})$. The bottom sea-ice temperature was stable from -0.5 to $-0.6^{\circ} \mathrm{C}$, corresponding to a brine salinity of 9-11 (Cox \& Weeks 1983).

The taxonomic analysis showed that the sea-ice community consisted of diatoms, cysts and flagellates (Fig. 2). The relative contributions of diatoms, total flagellates and cysts were not significantly different (\%; Mann-Whitney $U$-test).

The most abundant diatom genera were Nitzschia, Thalassiosira, Skeletonema, Cylindrotheca, Attheya, Navicula, Fragilariopsis and Chaetoceros. The flagellate groups (Fig. 3) encountered were chlorophytes (e.g., Chlamydonomas), cryptophytes, chrysophytes (e.g., Dinobryon) and dinoflagellates (including Alexandrium, Gymnodinium, Amphidinium and Prorocentrum), as well as some small unidentified flagellates.

Statistically significant variation among the melting procedures was apparent for most taxonomic groups, except diatoms and cryptophytes (Table 1): melting procedure A (direct melting at $20^{\circ} \mathrm{C}$ ) was statistically different to melting procedure $\mathrm{B}$ (direct melting at $4^{\circ} \mathrm{C}$ ) for total flagellates, chlorophytes and unidentified flagellates; was statistically different to melting procedure C (buffered melting at a salinity of 10) for chrysophytes and dinoflagellates; and was statistically different to melting procedure D (buffered melting at a salinity of 30) for
Table 1 Statistically significant difference (Mann-Whitney U-test, $P=0.05)$, based on abundance, between melting procedures: $(A)$ direct melting $\left(20^{\circ} \mathrm{C}\right)$; (B) direct melting $\left(4^{\circ} \mathrm{C}\right)$; (C) buffered melting (salinity of 10 ); and (D) buffered melting (salinity of 30 ).

\begin{tabular}{ll}
\hline & Significant difference \\
\hline Diatoms & - \\
Cysts & - \\
Total flagellates & $\mathrm{A}: \mathrm{B}$ \\
Chlorophytes & $\mathrm{A}: \mathrm{B}, \mathrm{A}: \mathrm{D}, \mathrm{B}: \mathrm{C}$ \\
Cryptophytes & - \\
Chrysophytes & $\mathrm{A}: \mathrm{C}, \mathrm{A}: \mathrm{D}$ \\
Dinoflagellates & $\mathrm{A}: \mathrm{C}$ \\
Unidentified flagellates & $\mathrm{A}: \mathrm{B}$ \\
Total algae & - \\
\hline
\end{tabular}

chlorophytes and chrysophytes. Statistical variation between the other three melting procedures is observed only for chlorophytes, where melting procedure B (direct melting at $4^{\circ} \mathrm{C}$ ) is statistically different to melting procedure C (buffered melting at a salinity of 10).

The melting time of the melting procedures differed: melting procedure A (direct melting) took 0.6 of a day; melting procedure B (direct slow melting) took 4.5 days; and melting procedures $\mathrm{C}$ and D (buffered melting, regardless of salinity) took 3 days.

\section{Discussion}

The sea-ice algal community consisted of diatoms, cysts and flagellates, with no significant difference in the relative composition (\%), regardless of the melting procedure. However, regarding specific flagellate groups (chlorophytes, chrysophytes, dinoflagellates and unidentified flagellates), melting procedure A (direct melting at $20^{\circ} \mathrm{C}$ ) was significantly different to one or more of the other melting procedures.

The melting time varied from 0.6 to 4.5 days, depending on the melting procedure. The melting time is relevant as algal growth and death, as well as predation, may influence the composition of the sea-ice algal community. The primary productivity of sea-ice algae in Kobbefjord has previously been quantified, ranging from $<1$ to $21 \mathrm{mg} \mathrm{C} \mathrm{m}^{-2} \mathrm{~d}^{-1}$ (Mikkelsen et al. 2008). In this study, samples from all melting procedures were melted in the dark to minimize the productivity of the sea-ice algae. With primary production minimized, there is an inherent risk that some algae will perish. In addition, predation may have an influence. Predators in sea ice include heterotrophic dinoflagellates and ciliates. Ciliates were observed, but in low abundance (data not shown), and the abundance of ciliates did not relate to the melting time (e.g., the ciliate abundance was similar in melting procedure A and D, which had melting times of 0.6 and 3 
days, respectively). Overall, if the melting time had significantly impacted the taxonomic composition, the samples would have been grouped according to melting time, with melting procedure B differing from C and D. The results of the taxonomic analysis show that melting procedure $\mathrm{B}, \mathrm{C}$ and $\mathrm{D}$ were significantly different to melting procedure $\mathrm{A}$, but not to each other, and that the influence of melting time is therefore negligible within the time range encountered in this study. However, seaice algal communities may sustain a higher abundance of protozoa, and the effect of melting time could thus vary. A general recommendation on melting time based on this study is to melt the samples slowly (>1 day), but not too slowly $(<1$ week).

The observed difference in taxonomic composition among melting procedures is observed for the following flagellate groups: chlorophytes, chrysophytes, dinoflagellates and unidentified flagellates. Based on limited samples, it has previously been suggested that direct melting (at an unspecified temperature) differs from melting in buffered water (Garrison \& Buck 1986). The effect of direct melting at $20^{\circ} \mathrm{C}$ on the sea-ice algal composition (this study) is presumably a consequence of flagellate cell lysis. This is supported by decreased abundance in samples melted by melting procedure A (Fig. 3).

As the sea-ice algal habitat undergoes large variations in salinity, it is likely that sea-ice algae exhibit increased halotolerance. Some sea-ice algae are known to remain physiologically active at a salinity of 129 (Stoecker et al. 1997), and might also be more tolerant to osmotic stress. Osmotic acclimation can be achieved by a variety of mechanisms, such as changed concentration of organic osmolytes (e.g., proline), ion transport and adapted morphological features (reviewed by Kirst 1989). The capability of sea-ice algae to adapt to osmotic stress if it is applied relatively slowly could explain the comparability of the "slow" melting procedures in this study (direct melting at $4^{\circ} \mathrm{C}$ and buffered melting).

This study has shown that sea-ice algae do not undergo cell lysis as a result of osmotic stress during sea-ice melt if a slow melting procedure is applied. The definition of a slow melting procedure is not exact, but it is recommended that melting time should be measured in days. While direct melting at $20^{\circ} \mathrm{C}$ should be avoided, melting procedures such as direct melting at $4^{\circ} \mathrm{C}$ and buffered melting at salinities of 10 and 30 render the sea-ice algae comparable for taxonomic analysis. This means that a comparison of data from a wide geographic and historical range is possible, which will increase our knowledge of the sympagic algal communities. Such a comparison, pooling existing data, would provide detailed background knowledge on the spatial, temporal and environmental patterns of sea-ice algal communities. However, for physiological measurements, the melting procedure remains important (e.g., Ryan et al. 2004), and should be considered carefully.

\section{Acknowledgements}

This project received funding from the Danish Energy Agency as part of the climate support programme to the Arctic. The work is a contribution to the Zackenberg Basic and Nuuk Basic programmes in Greenland.

\section{References}

Cox G.F.N. \& Weeks W.F. 1983. Equations for determining the gas and brine volumes in sea-ice samples. Journal of Glaciology 29, 306-316.

Garrison D.L. \& Buck K.R. 1986. Organism losses during ice melting: a serious bias in sea ice community studies. Polar Biology 6, 237-239.

Grasshoff K., Erhardt M. \& Kremling K. 1983. Methods of seawater analysis. Weinheim, Germany: Verlag Chemie.

Haecky P. \& Andersson A. 1999. Primary and bacterial production in sea ice in the northern Baltic Sea. Aquatic Microbial Ecology 20, 107-118.

Ikävalko J. 1998. Further observations on flagellates within sea ice in northern Bothnian Bay, the Baltic Sea. Polar Biology 19, 323-329.

Kirst G.O. 1989. Salinity tolerance of eukaryotic marine algae. Annual Review of Plant Physiology and Plant Molecular Biology 40, 21-53.

Medlin L.K. \& Priddle J. 1990. Polar marine diatoms. Cambridge: British Antarctic Survey.

Mikkelsen D.M., Rysgaard S. \& Glud R.N. 2008. Microalgal composition and primary production in Arctic sea ice-a seasonal study from Kobbefjord/Kangerluarsunnguaq, west Greenland. Marine Ecology Progress Series 368, 65-74.

Ryan K.G., Ralph P. \& McMinn A. 2004. Acclimation of Antarctic bottom-ice algal communities to lowered salinities during melting. Polar Biology 27, 679-686.

Stoecker D.K., Gustafson D.E., Merrell J.R., Black M.M.D. \& Baier C.T. 1997. Excystment and growth of chrysophytes and dinoflagellates at low temperatures and high salinities in Antarctic sea-ice. Journal of Phycology 33, 585-595.

Utermöhl H. 1958. Phytoplankton methodik. (Phytoplankton methodology.) Mitteilungen der Internationale Vereinigung für Theoretische und Angewandte Limnologie 9, 1-38.

von Quillfeldt C.H. 1996. Ice algae and phytoplankton in north Norwegian waters and Arctic waters: species composition, succession and distribution. PhD thesis, University of Tromsø. 